\title{
BRYOPHYTE FLORA OF THE VOLZHSKO-KAMSKIY NATURE RESERVE (TATARSTAN, EUROPEAN RUSSIA)
}

\author{
M. S. IGNATOV ${ }^{1}$, E. A. IGNATOVA ${ }^{2} \&$ N. A. KONSTANTINOVA ${ }^{3}$ \\ БРИОФЛОРА ВОЛЖСКО-КАМСКОГО ЗАПОВЕДНИКА \\ (ТАТАРСТАН, ЕВРОПЕЙСКАЯ ЧАСТЬ РОССИИ)
}

\author{
М. С. ИГНАТОВ ${ }^{1}$, Е. А. ИГНАТОВА ${ }^{2}$ И Н. А. КОНСТАНТИНОВА ${ }^{3}$
}

Abstract

On the basis of historical data and field studies conducted in 2003 and 2005, the bryopyte flora of Volzhsko-Kamskiy Nature Reserve presently includes 162 mosses, 44 liverworts, and 1 hornwort. Twenty doubtful records of previous authors are excluded. Raifa, one of two territories of the reserve, is known for its old-growth spruce forests and as the SW limit of Abies sibirica in Europe. This territory has relatively complete historical data on hepatics from the $1880 \mathrm{~s}$ and mosses since the 1920s. A comparison of the bryoflora found in our recent study with that documented earlier reveals changes in the bryoflora, particularly in representation of certain species. The maximal decreases are in epixylic species, associated with spruce and fir forests, and also in mire species. At the same time a relatively eutrophic epigeic forest species seems increase their abundance.

Резюме

В 2003 и 2005 гг. проведена инвентаризация бриофлоры Волжско-Камского заповедника, в котором насчитывается, учитывая старые гербарные сборы, 162 вида мхов, 44 вида печеночников, 1 антоцерот (не считая около 20 прежних указаний, отнесенных в разряд сомнительных). Раифский участок заповедника, известный своими вековыми ельниками и наиболее юго-западными популяциями пихты сибирской, был сравнительно подробно изучен в отношении печеночников с 1880 х годов и флоры мхов с $1920 x$ годов, что позволяет проанализировать историческую динамику бриофлоры. Наиболее значительное сокрашение видового состава отмечено среди эпискильных видов, так или иначе связанных с еловыми и пихтовыми лесами, а также среди болотных видов. В то же время, относительно эвтрофные наземные лесные виды стали встречаться, по-видимому, чаще.

\section{INTRODUCTION}

Volzhsko-Kamsky Nature Reserve includes two territories, Raifa and Saraly, separated by about $100 \mathrm{~km}$. Raifa Territory is situated to the West of the city of Kazan. The forest in this area was very little used over a period from 1674 to 1918, when it belonged to the Raifa Monastery. As a result, virgin spruce and fir forests were preserved here almost at the border with the steppe zone. These forests are considered the least disturbed ones in all of European Russia, and this fact readily explains the abundance of rare plant species known to occur in this area.

Botanical exploration of Raifa was initiated in the 1880s, and since the 1890s it has been a place of regular summer classes in botany and zoology for students of Kazan University. In the late 1920s, Raifa was given protected status, which, however, was removed in the 1930s. Later, partial protection status was given and removed on and off until 1960, when the site was officially protected as a reserve (Bakin, 2001). The protected area of Raifa Territory was 38.64 sq. km until 2000 when it was expanded up to $59.21 \mathrm{sq} . \mathrm{km}$.

1 - Main Botanical Garden of Russian Academy of Sciences, Botanicheskaya 4, Moscow 127276 Russia - Pocсия 127276 Москва, Ботаническая 4, Главный ботанический сад РАН

2 - Department of Geobotany, Biological Faculty, Moscow State University, Moscow 119899 Russia - Россия 119899, Москва, Московский университет, Биологический факультет, каф. геоботаники

3 - Polar-Alpine Botanical Garden-Institute of Kola Sci. Center of RAS, Kirovsk-6, Murmansk Province 184256 Russia - Poccия 184256, Мурманская область, Кировск-6, Полярно-альпийский ботанический сад-институт Кольского НЦ РАН 
Table 1. Temperature and precipitation (data of the meteorological station of the reserve in the Raifa Territory).

\begin{tabular}{lrrrr} 
Seasons & \multicolumn{3}{c}{ Temperature, ${ }^{\circ} \mathrm{C}$} & Precipitation \\
& average & $\max$ & $\min$ & $\mathrm{mm}$ \\
Spring & +5.1 & +10.6 & +1.1 & 118 \\
Summer & +17.3 & +24.1 & +10.9 & 226 \\
Autumn & +4.5 & +9.9 & +1.5 & 192 \\
Winter & -9.6 & --5.3 & -14.0 & 146
\end{tabular}

The forest in this new part of the reserve was cut in the second half of XX century, but 15-20 sq. $\mathrm{km}$ in the core area of the Raifa Territory, was not subject to clear cuttings for a long time, and the oldest woods here are 200-280 years old.

Saraly Territory is situated at the confluence of the Volga and Kama Rivers. An extensive water-reservoir established on the Volga River raised in the 1960s raised the level of the river more than 30 meters. As a result, there is a totally new beach area. Shortly before the establishment of the Reserve in 1960, forest in this territory was cut, so now rather few trees older than 60 years are scattered among relatively young pine and broad-leaved forests. The Saraly Territory has a protected area of $39.15 \mathrm{sq} . \mathrm{km}$.

Climate AND VEGETATION OF RAIFA

In Raifa Territory, the mean annual temperature is $+4.3^{\circ} \mathrm{C}$ and annual precipitation is $682 \mathrm{~mm}$ (see also Table 1). The soils in the area vary from sand to a relatively light loam.

Forests in the Raifa Territory are composed mostly of Pinus sylvestris and Tilia cordata (Table 2), especially if the forest is classified by the tallest tree, as it is done in this table. However the most intriguing is the role of Picea $\times$ fennica ( $P$. abies $\times P$. obovata). According to Ivanov (1995), in 1903, spruce occupied $24 \%$ of Raifa Territory, whereas in 1925 , only $1.8 \%$. This decline is obviously corresponds with the major forest-fire of 1921. Later, during the XX century, spruce started to spread, but in recent decades it declined again, and in 1993 it occupies less than $2 \%$ of the
Table 2. The percentage of territory covered by the main trees in Raifa and tendencies of their changes. Data are translated from Bakin \& Ivanov (2004), for the territory of 2611,45 hectars that was studied in 1925.

$\begin{array}{lrrrr}\text { Tree } & 1925 & 1958 & 1993 & \text { Tendency } \\ \text { Pinus sylvestris } & 61,5 & 56,0 & 53,1 & \text { decrease } \\ \text { Picea } \times \text { fennica } & 1,7 & 3,4 & 1,9 & \text { fluctuate } \\ \text { Quercus robur } & 6,1 & 3,0 & 1,1 & \text { decrease } \\ \text { Tilia cordata } & 17,4 & 19,8 & 23,2 & \text { increase } \\ \text { Betula pendula } & 10,8 & 14,8 & 18,1 & \text { increase } \\ \text { Populus tremula } & 2,3 & 2,1 & 1,2 & \text { descrease } \\ \text { Alnus incana } & 0,2 & 0,9 & 1,4 & \text { increase }\end{array}$

territory (Table 2). The latter figure, however, has to be compared with spruce undergrowth (Fig. 1). This illustrate spruce dynamics in one of the most common types of pine forest (Oxalis acetosellatype) from 1986-1991. The same pattern can be seen for almost all types of forests (Bakin \& Ivanov, 2004). No fire has occurred since 1991, thus in 2003 and 2005, when we conducted our studies of bryophytes, the representation of spruce became much greater, and many 'pine' forests looks now look more like spruce forests. Concurrently to this, the lichen-type of pine forest, which was relatively widespread ca. ten years ago, has changed almost everywhere to Pleurozium-type, while Pleurozium is being replaced by Calamagrostis arundinacea, Oxalis acetosella, Vaccinium mytryllus, ferns, etc. At the same time, Picea forests are being replaced by Tilia. At least, some Til$i a$ forests now have old, scattered trees of Picea.

Abies sibirica has a very limited occurrence in the Raifa, and it grows intermixed with spruce and Tilia. In recent decades, however, along with the decline of spruce, Abies has disappeared from many places where it was noticed in the mid-XX century. In 2003, we were able to find just a few small trees of Abies in forest compartments \#33 and \#37. These forests were especially wet and were rich in temperate bryophytes (e.g. Anomodon attenuatus and Fissidens taxifolius were
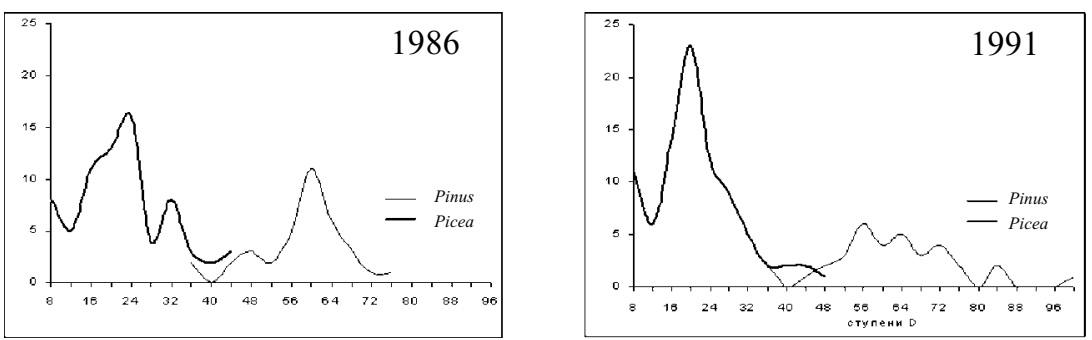

Fig. 1. Dynamics of Picea and Pinus in one of the permatent plots in Raifa in Pinus +Oxalis association 1986 and 1991: X trunk diameter; $\mathrm{Y}$ - number of trees per plot (from Bakin \& Ivanov, 2004, with permission) 
found only here), some of which (Anomodon longifolius, Neckera pennata, Homalia trichomanoides, etc.) were especially abundant here.

Old, broad-leaved forests (Quercus robur, Acer platanoides, Tilia cordata, Ulmus scabra, Fraxinus excelsior) are common now in a few areas, in the southern (\#65, 66, 67,78, 79, 80, 81), western (\#20,32, 33, 37, 46), and northwestern (\#1, 3) parts of reserve. Carex pilosa, Galeobdolon luteum, Mercurialis perennis, Matteuccia struthiopteris are dominants in the understory here. These broadleaved forests are rather open, thus favouring epiphytic vegetation composed of Anomodon longifolius, Leucodon sciuroides, Neckera pennata, Homalia trichomanoides, Dicranum viride, Pseudoleskeella nervosa, Platygyrium repens, etc.

Two small (3-5 m wide) creeks, Sumka and Ser-Bulak (Ser-Bulag), are crossing the Raifa Territory. Though these creeks are relatively small, their valleys increase the species diversity of this territory greatly: Sumka Creek has steep banks with eroded places that are the only place in Raifa where Fissidens bryoides grows in sufficient quantity.

The valley of Ser-Bulak Creek, and also in its ancient valley, forms a series of lakes and mires are formed. Some of what were lakes in the 1960s are transformed now to mires, with quite a soft quaking mat, but with no, or very limited, open water in their centres. These mires, and also boggy banks of lakes, are formed by Sphagnum fallax, S. teres, S. magellanicum, S. squarrosum, etc. In places, Helodium blandowii is quite common, but we failed to find Meesia triquetra and Hamatocaulis vernicosus, which were documented in Raifa by Ariskina in 1948 (KZN).

\section{SARALY TERRITORY}

Saraly Territory is a bank of the Volga-Kama water reservoir ('The Kuibyshev' Water-reservoir'), with elevations ranging from 50 to $120 \mathrm{~m}$. As the lower parts of slopes to the Volga and Kama Rivers were flooded in the 1950 and 60 s by the reservoir, the Territory presently comprises the middle part of actual slopes and a partly flattened watershed area. The soils are mostly sandy or otherwise light loamy.

This area is contrastingly different from Raifa in its vegetation. Spruce forests are absent (a few cultivations of spruce still exist, but look very unsuccessful). Pine and broad-leaved (mostly Tilia + Quercus) forests dominate; however they are mostly herbaceous. Mossy pine forests are found on dunes relief in the southern part of the Territory, and depressions in that area have a number of small (30-150 m across) Sphagnum bogs.

Broad-leaved forests in Saraly are much dryer than those in Raifa, so the composition of epiphytic mosses is much poorer. Pseudoleskeella nervosa is the most common species, and we were able to find Anomodon longifolius and Neckera pennata only few times, usually on solitary trees.

Ravines are also dry, and only two places were found with a relatively rich moss flora on eroded banks. One of these was along a road on a slope and another was in one of the ravines, which had, many tens of years ago, a road along its bottom.

Water-reservoir shores are occupied at places by a belt of Typha and Phragmites. The water level fluctiates $1(-2) \mathrm{m}$, leaving little space for mosses, while aglae completely dominant here, and Riccia and Ricciocarpos were found in a few places.

\section{BRYOLOGICAL EXPLORATION}

Saraly Territory has never been studied for bryophytes before, but Raifa Territory became a subject of bryological studies as early as 188283, when P. N. Krylov, a professor of Kazan University, undertook here his first botanical excursions here. His moss collections were identified by Brotherus and published later in an annotated list of mosses of Tatarstan (Krylov, 1904). Among 99 species in Tatarstan, 27 were reported from Raifa (obviously, most of them are quite common ones). Specimens are in KZN. It appears that Brotherus did not identify the whole collection, since some 'difficult' families, e.g. Brachytheciaceae, are totally absent in that publication. Hepatics collected by Krylov were identified and published later by Zenkova (1951). Her publication includes 41 species from the vicinity of Kazan, and 24 of them are reported for Raifa. These collections, as explained in that paper, are in TK.

A small addition to the moss flora was published by Ponomarev (1913). Then, in 1929, the Raifa forest was studied by L. N. Vasil'eva. She collected a fairly complete set of bryophytes, but published only the list of Sphagnum species (Vasil'eva, 1933). However her moss collection is preserved in KZN. It includes 92 species 
(among them 15 Sphagna and 7 hepatics), each represented by one (occasionally two) specimens, with a short label, identifying the forest compartment [the collections are mostly made by Vasil'eva, although a few are by Pletneva].

In 1948, the territory of Raifa forest was explored by N. P. Ariskina, who later published a list of Raifa' bryophytes (Ariskina, 1968). Her list includes 160 species, many of them annotated with data on habitats, associated species and frequency. The basis for this list includes her own collections of 1948 (now in KZN), and also specimens from Vasil'eva's collection, although there is no published reference on the latter. However, from a comparison of the paper of Ariskina and the herbarium of Vasil'eva in KZN, this fact is absolutely clear. Moreover, several specimens from the Vasil'eva' collection were obviously divided and part of them supplied with a new label "Raifa, coll. Ariskina, 1960". These circumstances are considered in the historical analysis below.

In 2003 and 2005, the territory of the entire Volzhsko-Kamskiy Nature Reserve was re-studied by Ignatov and Ignatova. Their moss collections are in MHA, with most duplicates in MW, and their hepatics, which were identified by Konstantinova, are in KPABG, with almost complete set - in MHA and MW.

\section{LIST OF SPECIES}

Ariskina's 1968 list has a special mark (asterisk) for species that were collected by her for the first time, but it is impossible to find out if she recorded species found by prior authors. For the sake of maximal information retension, in the following list, we indicate species reported first by Ariskina with $\mathrm{A}++$, and those not reported first by Ariskina with $\mathrm{A}+$. An A-indicates species not reported by Ariskina (1968), and !A denotes specimens in KZN (mostly from 1948, all of them verified).

Records from Krylov (1904) are marked K+; those of Zenkova (1951) are marked Z+; those of Vasil'eva (1933) are marked $\mathrm{V}+$; and the presence of specimen(s) in the Vasil'eva' collection in KZN are marked $\mathrm{VH}+$.

Forest compartments (about $100 \mathrm{ha}$ ) are indicated for more rare species with \#. For the 2000 addition to the Raifa Territory, the compartments are indicated by \#N.
Annotations are followed by the number of one representative specimen, in square brackets [the number is the collector number of Ignatov \& Ignatova, except for some hepatics, where the accession number of the KPABG herbarium is given].

\section{HORNWORT}

Anthoceros agrestis Paton - Saraly: One population (several tens plants) on wet long unused road in open Salix stand, \#10. [05-2216].

\section{LIVERWORTS}

Blasia pusilla L. - Raifa: Z-, A-. Common now on sandy, loamy and clayey soil along forest roads and trails, on edges of openings, under upturned roots of fallen trees, at lake shores, landslides of Ser-Bulak and Sumka Creeks. Saraly: on wet long unused road in open Salix stand, \#10 [05-2216].

Blepharostoma trichophyllum - Raifa: Z+ (many places, on rotten wood of coniferous and deciduous trees, also on stumps; occasionally on substrates other than rotten wood; associated species are Cephalozia connivens, Liochlaena lanceolata, Riccardia latifrons, $R$. palmata, Leiocolea heterocolpos, Crossogyna autumnalis, Lophozia longidens,Lepidozia reptans). A+. We did not find it despite special search.

Calypogeia integristipula Steph. (incl. old records of C. neesiana (C. Mass. et Carest.) K. Muell.) - Raifa: $\mathrm{Z}+(C$. neesiana: forest at lake shore, on almost totally decomposed rotten log, with Lepidozia reptans). $\mathrm{A}+$. We found this species few times, on rotten wood in spruce forest and at mire-forest border, $\# 126,131$, 134, 67 [05-2255].

C. muelleriana (Schiffn.) Muell. Frib. (incl. old records of C. trichomanis (L.) Corda) - Raifa: Z+ (wet coniferous forest at swampy lake shore, admixture to Lepidozia reptans). A+. We found this species once in Pinus + Picea forest, on the edge of pool, on sandy soil (\#47), with gemmae [KPABG 106356].

Cephalozia bicuspidata (L.) Dumort. (incl. C. lammersiana (Hueb.) Carring.) - Raifa: Z+ (in wet deciduous and coniferous forest at lake shore and near peatbog, on bark of coniferous trees; assosiated with Ptilidium pulcherrimum, Blepharostoma trichophyllum, Liochlaena lanceolata, Crossocalyx hellerianus, Chiloscyphys profundus, Crossogyna autumnalis, Tritomaria exsecta). A+. We collected it along the road in Pinus + Picea forest (\#145/146), and in bog "Gniloye" (\#133/134), at the base of sedge tussock and on decaying wood on the edge of bog [05-2270, 05-2301]. With perianths, once with sporophyte.

C. connivens (Dicks.) Lindb. - Raifa: Z+ (in wet and moist coniferous and decidious forest, on decaying substrates, with Blepharostoma trichophyllum, Riccardia palmata, Crossogyna autumnalis, Chiloscy- 
phus profundus, Liochlaena lanceolata). A+. We collected it only once on the edge of small Sphagnum mire in Pinus-Picea forest, \#130 [KPABG 106361].

C. lunulifolia (Dumort.) Dumort. - Raifa: Z-, A-. In the mire near Dolgoe Lake, south edge (\#126), on decaying stump, mixed with Calypogeia integristipula; in the mire "Gniloe" (\#134), at base of sedge tussock, mixed with Cephalozia pleniceps, C. bicuspidata, Cephaloziella elachista [05-2244a].

C. pleniceps (Austin) Lindb. - Raifa: Z-, A-. In the mire "Gniloe" (\#134), at base of sedge tussock, mixed with Cephalozia lunulifolia, C. bicuspidata, Cephaloziella elachista [05-2244b]. Many plants with gemmae, perianths and androecia.

Cephaloziella elachista (J.B.Jack ex Gottsche et Rabenh.) Schiffn. - Raifa: Z-, A-. In the mire "Gniloe" (\#134), at base of sedge tussock, mixed with Cephalozia lunulifolia, C. bicuspidata, C. pleniceps [05-2244c]. Many plants with perianths and androecia, autoicous.

C. rubella (Nees) Warnst. - Raifa: Z-, A-; Sporadically [e. g. \#19/13, 145/146, 146] in pine (or occasionally other types) forests on sandy soil banks along roads and especially in fire-preventing trenches, often with Buxbaumia aphylla and Isopaches bicrenatus [KPABG 106350]. Always with perianthia, androecia and sporophytes; heteroicous.

Chiloscyphus minor (Nees) Engel et Schust. (Lophocolea minor Nees) - Raifa: Z+ (moist coniferous and decidious forest at lake shore); $\mathrm{A}+$; collected now on trunks of deciduous trees in southern part of the territory, associated with Anomodon longifolius, Pseudoleskeella nervosa, etc., and on decaying wood on the shore of forest lake, \#65. Saraly: sandy soil banks of roads on steep slope in forest, \#24, 55 [052170].

C. polyanthos (L.) Corda (incl. C. pallescens (Ehrh.) Dum.) - Raifa: Z+ (moist coniferous and decidious forest at lake shore, as $C$. pallescens); $\mathrm{VH}+(\# 35)$; $\mathrm{A}+$. Now collected several times on wet soil and decaying wood on shores of inundated bank of SerBulak Creek, on shores of lakes in bogs, \#31, 32, 33, 134, 142. Saraly: on wet soil among Phragmites on shore of gulf of water-reservoir [KPABG 109461].

C. profundus (Nees) Engel et Schust. (= Lophocolea heterophylla (Schrad.) Dum.) - Raifa: Z+ (many places, on rotten logs and stumps, also on trunks of coniferous trees; associated species are Crossocalyx hellerianus, Chiloscyphus profundus, Crossogyna autumnalis, Blepharostoma trichophyllum, Cephalozia connivens, Lophozia ventricosa var. guttulata). Quite common now on rotten wood, at tree bases, and also on soil banks along trails and fire-preventing ditches. Saraly: moderately common in similar habitats [05-2029].
Cladopodiella fluitans (Nees) H.Buch (Cephalozia fluitans (Nees) Spruce) - Raifa: A++. In pools in Carex + Sphagnum bog (\#49). Not found by us; herbarium unknown.

Conocephalum conicum (L.) Dum. - Raifa: Z+ (moist coniferous and decidious forest at lake shore, with Chiloscyphus pallescens); $\mathrm{VH}+$ (\#66, ravine); the specinen labelled as "coll. Ariskina, 1960" is apparently taken from VH. Saraly: In abundance in one of deep ravines (with Polystichum braunii) [05-2029].

Crossocalyx hellerianus (Nees ex Lindenb.) Meyl. (Sphenolobus hellerianus (Nees) Steph.; Anastrophyllum hellerianum (Nees ex Lindenb.) R.M.Schust.) Raifa: Z+ (in wet coniferous forest on decaying stump; associated species include Lepidozia reptans, Crossogyna autunnalis, Chiloscyphys profundus, Lophozia ventricosa var. guttulata). A+. We did not find this species.

Crossogyna autumnalis (DC.) Schljakov (Jamesoniella autumnalis (DC.) Steph.) - Raifa: Z+ (many places, moslty on rotten wood; associated species are Lepidozia reptans, Crossocalyx hellerianus, Cephalozia connivens, Blepharostoma trichophyllum, Ptilidium pulcherrimum, Chiloscyphys minor, C. profundus, Lophozia ventricosa, L. ventricosa var. guttulata, Schistochilopsis incisa). A+. We collected it only once: in Tilia+Quercus forest, on the base of old Quercus robur, in \#80 [KPABG 106367].

Isopaches bicrenatus (Schmid. ex Hoffm.) H.Buch Raifa: Z-, A-. Sporadically [e. g. \#19/13, 145/146, $146]$ in pine (or occasionally other types) forests on sandy soil banks along roads and especially in firepreventing trenches, often with Cephaloziella rubella [KPABG 106350]. Always with gemmae, often with sporophytes.

Leiocolea heterocolpos (Thed.) Buch - Raifa: Z+ (forest at lake shore, on decaying log of coniferous tree, with Blepharostoma trichophyllum and Liochlaena lanceolata). A+.We failed to find this species.

Liochlaena lanceolata Nees (Jungermannia lanceolata Schrad.) - Raifa: Z+ (on decaying wood and occasionally on rotten bark of standing trees, with Lepidozia reptans, Blepharostoma trichophyllum, Cephalozia connivens; Chiloscyphus profundus, Ptilidium pulcherrimum). $\mathrm{A}+$.We failed to collect this species.

Lepidozia reptans (L.) Dum. - Raifa: Z+ (many places, on rotten wood and at bases of coniferous trees; associated species are Blepharostoma trichophyllum, Calypogeia neesiana, Liochlaena lanceolata, Riccardia latifrons, etc.). A+. All our special attempts to find this species were unsuccessful.

Lophozia excisa (Dicks.) Dum. - Raifa: Z-, A-. On the western edge of $\# 139$, on moist sandy soil along the border of Pinus + Picea forest and meadow, with 
Scapania irrigua; in \#145/146 in Pinus +Picea forest, on soil with Chiloscyphus profundus[KPABG 106352]. In all collections with perianths, androecia and sporophytes.

L. longidens (Lindb.) Macoun - Raifa: Z+ (in wet coniferous forest, swamp, at lake shore - always on rotten stumps; with Lophozia ventricosa, Crossogyna autumnalis, Blepharostoma trichophyllum, Schistochilopsis incisa). A+. We collected this species two times: in Picea+Tilia forest, on horizontal trunk of Tilia (\#37) and in Pinus forest on decaying stump (\#47) [KPABG 106354].

L. ventricosa (Dicks.) Dumort. - Raifa: Z+ (in wet, usually coniferous forests on strongly rotten wood; with Crossogyna autumnalis, Ptilidium pulcherrimum, Lophozia longidens, Scapania irrigua, Blepharostoma trichophyllum, Schistochilopsis incisa). $\mathrm{A}+$. We did not find the type variety of this species. —var. guttulata (Lindb. et Arnell) Bakalin - Raifa: Z+ (Zenkova did not include this taxon in her list, but Lophozia guttulata is mentioned as a species associated with Chiloscyphus profundus, Croccocalyx hellerianus and Crossogyna autumnalis). A-. We found it once, in Pinus + Picea forest, along compartment line \#145/146, mixed with Cephalozia bicuspidata [KPABG 109475]. With perianths.

Mannia fragrans (Balbis.) Frye \& L.Clark - Saraly:(\#13) steppe slope to the Volga River (KPABG: \#G107108, leg. G.Urbanavichus, 27.IX.2002, det. V.Bakalin).

Marchantia polymorpha L. s. 1. - Raifa: Z+ (on soil in forest at lake shore: two forms are reporped, f. domestica Wahlenb. and f. aquatica $\mathrm{Nees}$ ); $\mathrm{VH}+$ (along a road); $\mathrm{A}+$. Common now in various disturbed places, wet forest roads and trails, inundated lake and stream bars, occasionally under upturned roots of fallen trees. Saraly: similar habitats and on open wet places at base of slope to water-reservoir [05-2168].

Pellia endiviifolia (Dicks.) Dum. - Raifa: VH+ (\#35); the specimen labelled as "\#35, coll. Ariskina, 1960" is apparently taken from VH. A++. Saraly: On wet unused road in open Salix stand, \#10. [05-2207].

P. epiphylla (L.) Corda - Raifa: A++ (banks of Ser-Bulak Creek). We did not find this species, herbarium is unknown. Maybe this record should be referred to the next species.

P. neesiana (Gottshe) Limpr. - Raifa: Z-, A-. Sporadically on soil at banks of Sumka and Ser-Bulak Creeks, on bottom of ravine near Dolgoe Lake and in the bog "Mokhovoe", \#20, 125, 126, 134, 145 [KPABG 109457]. Most specimens have androecia, and one - involucres.

Plagiochila porelloides (Torrey ex Nees) Lindenb. (Plagiochila asplenioides subsp. porreloides (Torrey ex Nees) Kaal., Plagiochila asplenioides auct.) - Raifa:
$\mathrm{Z}+$ (on trunks of coniferous trees in wet forest at lake shore; epiphytic growth is not characteristic for this species, and this is specially underlined by the author). $\mathrm{VH}+(\# 67$, sub Mylia anomala). Specimens in herbarium of Ariskina (collection of Maksyutina) belong to Homalia trichomanoides. It was very surprising to us, but we failed to find this species.

Ptilidium pulcherrimum (G. Web.) Vaino - Raifa: Z+ (many places, on living trunks and rotten logs and stumps; associated species are Blepharostoma trichophyllum, Crossocalyx hellerianus, Cephalozia bicuspidata, C. connivens, Tritomaria exsecta, Chiloscyphus profundus, C. minor, Liochlaena lanceolata, Crossogyna autumnalis, Lophozia longidens, L. ventricosa, Schistochilopsis incisa). $\mathrm{A}+\mathrm{VH}+(\# 40$, sub P. ciliare); A+. Very common now throughout the reserve on standing trunks, rotten wood, sometimes on wood of forest compartment posts. Saraly: not rare, though less common than in Raifa [KPABG 106380].

Radula complanata (L.) Dum. - Raifa: Z+ (on deciduous tree at lake shore - from annotation one can assume, that this was a single collection). A+. Now this is a very common species on trunks of old deciduous trees, as well as on Salix spp. and Populus tremula. Saraly: Sporadic in the same habitats [052207].

Riccardia latifrons Lindb. - Raifa: Z+ (swamp in spruce forest, strongly rotten $\log$, as admixture to Lepidozia reptans; also mentioned as associated species of $R$. palmata in moist coniferous and decidious forest at lake shore, on rotten logs of deciduous trees, with R. palmata and also Lophozia ventricosa, Leiocolea heterocolpos, Cephalozia connivens, Crossogyna autumnalis. $\mathrm{A}+$. Not found by us.

R. palmata (Hedw.) Carr. - Raifa: $\mathrm{Z}+$ (moist coniferous and decidious forest at lake shore, on rotten logs - two collections: one with Solenostoma sphaerocarpa, Blepharostoma trichophyllum, Cephalozia connivens; another with $R$. latifrons, Lophozia ventricosa, Leiocolea heterocolpos, Cephalozia connivens, Crossogyna autumnalis). A+. Not found by us.

Riccia canaliculata Hoffm. - Raifa: Z-, A-. Found once, in \#31 in mesotrophic mire (Comarum palustre, Carex rostrata) west of Sadovy settlement, on wet peat. Saraly: \#54: small swamp in forest; \#10: on wet unused road in open Salix stand [05-2320].

$R$. cavernosa Hoffm. - Saraly: On wet soil on inundated shores of water-reservoir (\#13, \#34) and of ponds (\#10), and on wet unused road in open Salix stand (\#10) (KPABG \#G107109, \#G107111, leg. G.Urbanavichus, 26.IX.2002, det. V.Bakalin).

R. fluitans L. - Raifa: A++ (Karasikha Lake). We collected it in \#37, 65, 126 in pools in bogs and in lakes near shores. Saraly: \#61, 62, 34 sporadic on period- 
ically flooded openings within Typha angustifolia belt of gulf shores, and also among hummocks in flooded parts of swamps [05-2212].

$R$. glauca L. - Saraly: Hay meadow, in places with relatively sparse grasses (\#80), on soil on meadow and along old (not-used few years) forest road, on moist soil (\#10) [05-2147].

$R$. sorocarpa Bisch. - Saraly: On soil on meadow and along old (not-used few years) forest road, on moist soil, \#10, 56 [05-2226].

Ricciocarpos natans (L.) Corda - Saraly: \#61: on soil, in dry channel (KPABG \#G107112, \#G107113, leg. 1.X.2002 G.Urbanavichus; det. V.Bakalin).

Scapania irrigua (Nees) Nees - Raifa: Z+ (on soil in wet forest at lake shore). A+. We found it at the western edge of \#139, on moist sandy soil along the border of Pinus + Picea forest and meadow, with Lophozia excisa [KPABG 106353].

Schistochilopsis incisa (Schrad.) Konstantinova (Lophozia incisa (Schrad.) Dumort. - Raifa: Z+ (On decaying wood in peat bog, with Lophozia longidens and $L$. ventricosa). A+. We did not collect this species.

Solenostoma sphaerocarpum (Hook.) Steph. (Aplozia sphaerocarpa (Hook.) Dumort., Jungermannia sphaerocarpa Hook.) - Raifa: Z+ (in wet deciduous and coniferous forest on lake shore, with Riccardia palmata, Blepharostoma trichophyllum, Cephalozia connivens). A+. Not found by us.

Tritomaria exsecta (Schmidel ex Schrad.) Loeske (Sphenolobus exsectus (Schmidel ex Schrad.) Steph.) - Raifa: Z+ (in wet deciduous and coniferous forest on bark of coniferous tree, one collection; accosiated with Cephalozia bicuspidata, Ptilidium pulcherrimum, Blepharostoma trichophyllum, Crossocalyx hellerianus, Chiloscyphys profundus, Crossogyna autumnalis). A+. We did not find this species. MOSSES

Abietinella abietina (Hedw.) Fleisch. - Raifa: $\mathrm{VH}+(\# 51)$. $\mathrm{A}++$ (rather frequent in openings and forest edges). We found it in a few places on relatively moist meadow, $\# 139$ N, 136N. Saraly: One finding, where it is locally abundant on hay meadow, at border of \#56 [05-2148].

Amblystegium serpens (Hedw.) B.S.G. (incl. A. juratzkanum Schimp.) - Raifa: $\mathrm{VH}+$ (\#66), $\mathrm{A}++$ (common on trunk bases of deciduous trees, rotten logs, stumps, damp soil). Similarly abundant now in the same habitats; especially common in flood valleys on trunks and logs covered by alluvium. Saraly: Common in similar habitats [05-2060].

Anomodon attenuatus (Hedw.) Hueb. - Raifa: A-. We found this speices on Tilia trunks in Tilia+Picea forest $(\# 32,37)$, only on three trees, on two of them it forms extensive mats up to $1.5 \mathrm{~m}$ above ground on upper surface of inclined trunks [03-1].
A. longifolius (Brid.) Hartm. - Raifa: $\mathrm{VH}+(\# 80)$; ! + (not common). In old Tilia+Picea forests and broadleaved forests, rather frequent (although somewhat rarer than Neckera and Homalia). Recorded by us in two areas: ( $\# 65,66,67,78,79,80,81)$ and $(\# 32,33$, 37). Saraly: On Tilia in old forests and in ravines, usually in small quantity, \#10, 26, 44, 54 [05-2181].

A. viticulosus (Hedw.) Hook. et Tayl. - Raifa: VH+ (\#53); !A+ (base of Ulmus, on slope of ravine - specimens in herbarium of Ariskina ('1960') seem to be taken from herbarium of Vasil'eva). Not found by us. Atrichum angustatum (Brid.) B. S. G. - Raifa: A-. In few places along the trench in pine forest at the reserve border; some populations up to several meter long, \#1,3,5. Saraly: Soil bank of road in forest on steep slope, \#24 [05-2338].

A. flavisetum Mitt. (A. haussknechtii Jur. et Milde) Raifa: $\mathrm{VH}+$; !A+ (rare - specimens in Ariskina herbarium in KZN dated by 1960 are probably taken from Vasil'eva' collection). We found this species in one place, under upturned roots of fallen tree in spruce forest, \#142. Saraly: Sporadic, in similar habitats in various types of forest, more rarely on ravine slopes [05-2026].

A. tenellum (Röhl.) B. S. G. - Raifa: A-. Found in few places on sandy soil banks at the edge of pine forest in \#139 [03-3].

A. undulatum (Hedw.) P. Beauv. - Raifa: $\mathrm{VH}+$; !A++ (rather common). Common now on bare soil in forests, both natural (ravine slopes, landslides at creek banks, under upturned roots of fallen trees), as well as along roads and trenches; occasionally on moist meadows (forest openings) among herbs. Saraly: Sporadic on slopes of ravines and soil banks along roads and compartment lines [05-2036].

Aulacomnium palustre (Hedw.) Schwaegr. - Raifa: K+; $\mathrm{VH}+(\# 67) ; \mathrm{A}+$ (common in mires of different types). Now similarly common; it grows besides mires also at forest edge and compartment lines; on moist, but occasionally also on relatively dry soil. Saraly: In small bogs in inter-dune depressions; once on slate roof at the station of reserve ("Nizhnij Kordon") [052077].

Barbula convoluta Hedw. - Saraly: Rare, along roads in rather open pine forest, \#7, 55 [05-2193].

B. unguiculata Hedw. - Raifa: A-. Rare, on damp soil along roads and on meadow on west shore of Raifa Lake, among sparse grasses, with Tortula truncata. Saraly: regularly found at base of steep eroded slope to water-reservoir, at places very slightly seeping by ground water; occasionally on meadow and along roads [05-2118].

Brachytheciastrum velutinum (Hedw.) Ignatov et Huttunen (Brachythecium velutinum (Hedw.) B.S.G.) Raifa: $\mathrm{VH}+(\# 37)$; $\mathrm{A}++$ (as rather common in fo- 
rests). We found this species few times - on soil along road and compartment lines in forests (both pinemossy type and mixed Picea+Tilia-type); occasionally on thin fallen twigs. Saraly: Rare, on soil banks along roads (usually on subvertical faces) and on dry fallen logs [05-2088].

Brachythecium albicans (Hedw.) B.S.G. - Raifa: VH+ (\#50); A++ (sporadic in open forests). Now rather frequent in pine forests (along roads, trenches, forest edges, etc.). Saraly: In grasslands at forest edges $(\# 10,56)$ [05-2156].

B. campestre (Müll. Hal.) B.S.G. - Raifa: A++ (rather common on soil in open forests, with Abietinella and Polytrichum juniperinum; there is no collection in her herbarium in KZN, while in Vasil'eva herbarium so-called specimen belongs to B. rutabulum). We collected this species several times on broad lines within forest and at forest edges. Saraly: On soil on openings in forests, once of rotten log [05-2176].

B. erythrorrhizon B. S. G. ssp. asiaticum Ignatov Raifa: A-. On soil in swampy Pinus +Picea forest, \#145 [03-6].

B. mildeanum (Schimp.) Schimp. - Raifa: A++ (sporadic, on wet places in forests and mire edges). Sporadic now too; we found it mostly in open places cuttings, openings in forest, forest edges, creek bars, on soil and occasionally on rotten wood covered by alluvium in flood valley. Saraly: Within Phragmites belt along gulfs, occasionally in other wet places in depressions [05-2063].

B. rivulare B.S.G. - Raifa: A++ (rare, \#9, on log at creek bank, with Leptodictyum). We confirm the rare occurrence of this speices in Raifa (despite its abundance in most regions of European Russia). We found it twice in \#20, on landslides to Sumka Creek, and \#126, in ravine south of Dolgoe Lake, on rotten stump [03-7].

B. rotaeanum De Not. - Raifa: A-. Previous authors usually did not separate this species from $B$. salebrosum. It is relatively common now, growing mostly on trunks of broad-leaved trees, especially on inclined ones. Saraly: In similar habitats, and twice on sandy soil banks [05-2057].

B. rutabulum (Hedw.) B.S.G. - Raifa: $\mathrm{VH}+(\# 81$, sub B. campestre); $\mathrm{A}++$ (tree bases, exserted roots, on soil). We found it only once, \#20, on rotten log at Sumka Creek bank. Saraly: Rare, on soil along road, \#10 [05-2201].

B. salebrosum (Web. et Mohr) B.S.G. - Raifa: VH+ (\#81); !A++ (common on trunks, logs, soil). The frequency and habitats remain the same. Saraly: Rather common in pine and birch forests, usually on rotten logs, also on inclined trunks, trunk bases, on soil (especially along roads) [05-2033].

Breidleria pratensis (Koch ex Spruce) Loeske (Hypnum pratense Koch ex Spruce) - Raifa: A++ (mires and along brooks in forest, sporadic - but no herbarium specimens found). We failed to find this species.

Bryum argenteum Hedw. - Raifa: A-. Rare, on wet loamy soil along roads in forest. Saraly: Not abundant, but regularly occurring along the banks of water-reservoir, on wet places at slope bases (especially below landslides, ocasionally in wet places along roads, on old brick walls, etc. [05-2190].

B. caespiticium Hedw. - Raifa: A++ (not frequent, on soil in mixed forest). We found it few times at pine forest edge on oligotrophic meadow communities. Saraly: Sporadic, on steep slopes to water-reservoir, on soil in Salix shrubs, on concrete blocks at pond bank and in reserve station [05-2040].

B. capillare Hedw. - Raifa: $\mathrm{K}+$; ! + + (pine forest, on soil, rare). We recorded this species as a quite common in forest compartment lines and along fire-prevention trenches, on sandy and loamy soil, usually in pine forests. Always sterile. Saraly: Sporadic on soil in openings, mostly in Pinus +Betula forests [052215].

B. intermedium (Brid.) Bland. - Raifa: $\mathrm{A}++$ (on wet sandy soil in pine forest, rare). Not found by us.

B. lonchocaulon Müll. Hal. (B. cirrhatum Hoppe et Hornsch.) - Raifa: A++ (sporadic at forest edges). We did not find this species. Saraly: \#62, on the shore of water-reservoir, on log, covered by alluvium [052218].

B. moravicum Podp. (B. laevifilum Syed) - Raifa: A-. One collection at Sumka Creek bank, on fallen log, \#20. Saraly: Vertical sandy soil banks along roads in forests, \#24, 33 [05-2047].

B. pallens Sw. - Raifa: A- (on wet soil on shore of Dolgoe Lake, \#126 [03-10].

B. pseudotriquetrum (Hedw.) Gaertn. et al. - Raifa: $\mathrm{A}++$ (rare on soil in forest). We collected it several times on wet soil on meadows and along forest roads, once on rotten log at creek bank [03-11].

Buxbaumia aphylla Hedw. - Raifa: $\mathrm{VH}+(\# 25 / 30$, collection of 1931); A++ (very rare in dry pine forests). We found it few times on banks of fire-prevention trenches, usually associated with Cephaloziella rubella. The suitable places are much more common, than the plant itself, and than Cephaloziella rubella. Saraly: Two collections, along forest road and under upturned roots of fallen trunk, on sand covered rotten roots [05-2020].

Callicladium haldanianum (Grev.) Crum - Raifa: $\mathrm{VH}+$ (\#81); !A++ (rather common, on stumps and trunk bases). The species is common now, occurring in the same habitats, but preferring recently fallen logs, usually dominating on their upper and side surfaces. Saraly: Sporadic to common on rotten logs in different forest types [05-2017]. 
Calliergon cordifolium (Hedw.) Kindb. - Raifa: K+; $\mathrm{VH}+(\# 53)$ ) ! A+ (in \#26 in Carex swamp and along Ser-Bulak Creek banks). According to our observations, it is a common species, occurring at edges of wet depressions in conifer forest and various swamps and mires, in Alnus gluticosa swamps, temporarily dried creek beds, etc. Saraly: small bogs in depressions between dunes, more rarely on gulf banks (among Phragmites and Typha) [05-2070].

C. giganteum (Schimp.) Kindb. - Raifa: !A++ (in mires, not common; in her collection in KZN is a specimen from Goluboe Lake, 18.VII.1948, where this species is mixed with Drepanocladus aduncus). We failed to find this species now.

Calliergonella cuspidata (Hedw.) Loeske - Raifa: VH+ (\#67); A++ (in Carex swamps and in mire in \#53, sporadic). Not found now despite intentional search.

C. lindbergii (Mitt.) Hedenäs (Hypnum lindbergii Mitt.) - Raifa: $\mathrm{VH}+(\# 51)$; !A++ (common in eutrophic and mesotrophic mires). In those habitatats found few times (in big quantity - in mire west of Sadovyj settlement); more common along wet forest edges bordered by oligotrophic meadows, and also on small meadows among forest. Saraly: rare, on wet soil at gulf bank, in small swamp among forest and in depression on hay meadow [05-2137].

Campylidium sommerfeltii (Myr.) Ochyra (Campylium sommerfeltii (Myr.) J.Lange) - Raifa: A? (Ariskina reported $C$. hispidulum in $\# 70$, in wet depression, in water, a habitat not common for the species). We collected this species several times on rotten logs (as it commonly grows in Central Russia) along Sumka and Ser-Bulak Creeks, and also in the relatively wet Tilia forests and mixed forests with spruce. Saraly: Rare, on soil bank along a forest road and on inclined trunks of Salix and Padus at gulf shore (\#32) [05-2128].

Ceratodon purpureus (Hedw.) Brid. - Raifa: $\mathrm{K}+; \mathrm{VH}+$ (\#51); !A+ (very common on soil in forest and along roads, also on stumps). Common on soil in seminatural (forest edges, open pine forests) and secondary places; also on trunks (especially on Betula), bricks, concrete, old roofs. Saraly: Common on slopes to water-reservoir, not rare also in other habitats [05-2230].

Cirriphyllum piliferum (Hedw.) Grout - Raifa: VH+ (\#66, ravine); ! $A++(\# 66$, ravine). Now it was found many times in ravines and in forests with more or less dense spruce [03-16].

Climacium dendroides (Hedw.) Web. et Mohr - Raifa: $\mathrm{VH}+(\# 67) ; \mathrm{A}++$ (frequent, in wet forests and in swamps, on soil and stumps). Frequency and habitats remain the same; occasionally grows on aspen trunks up to 1-2 m above ground. Saraly: Sporadic, on soil in small swamps and along gulf shores [05-2199].
Dicranella cerviculata (Hedw.) Schimp. - Raifa: A-. We found this species three times: \#130N (under upturned roots at swamp edge), \#126 (same habitat), \#47 (sandy-loamy soil bank of deep karst depression) [03-19].

D. heteromalla (Hedw.) Schimp. - Raifa: A++ (\#39; one locality, at the edge of swamp). Now it is common along trenches and compartment lines in different types of forest, including relatively dry pine forests; sporadically occuring under upturned roots of fallen trees (especially in forests with spruce. Saraly: Rare, on soil banks along forest roads and under upturned roots [05-2122].

D. schreberiana (Hedw.) Hilp. ex Crum et AndersonSaraly: Track pit of old forest road in \#10 [05-2219].

D. varia (Hedw.) Schimp. - Raifa: A-. On wet soil along a road near Belobezvodnoye, and at Tilia forest edge in \#1 and \#80. Saraly: Track pit of old road in \#55, single collection [05-2169].

Dicranum bergeri De Not. - Raifa: !A- (although not listed by Ariskina, there is correctly identified specimen in her herbarium in KZN dated "18.VII.1948"). We collected it in mire near Dolgoe Lake (\#125), at a relatively oligotrophic place [03-22].

D. bonjeanii De Not. - Raifa: $\mathrm{VH}+(\# 51)$; !A++ (\#51, in mesotrophic mire). We found this species once, \#67, on rotten stump in swampy bottom of a broad ravine [03-23].

D. flagellare Hedw. (Orthodicranum flagellare (Hedw.) Loeske) - Raifa: $\mathrm{K}+$; $\mathrm{VH}+(\# 40)$; ! + (sporadic, on bases of trunks, especially of Pinus and Picea, and also on rotten stumps). Current frequency and habitats are the same. The occurrence on pine bases is interesting - we never observed it to be so frequent in this habitat in other parts of European Russia [0324].

D. montanum Hedw. (Orthodicranum montanum (Hedw.) Loeske) - Raifa: VH+ (\#34); !A++ (common on trunks, especially on Betula). Very common on rotten logs and trunks in various forests. Saraly: Common in similar habitats [05-2018].

D. polysetum Sw. - Raifa: $\mathrm{VH}+(\# 40)$; ! + (very common on soil in forests, especially in pine forests). Common, in relatively dry pine forest (substituting lichens, and being substituted further by Pleurozium), more rarely in other type of forests, on soil, trunk bases, rotten logs, hummocks in bogs, etc. Saraly: Common, in pine forests, both dry and wet and boggy [05-2010].

D. scoparium Hedw. - Raifa: VH+ (\#67, 70); !A+ (common on soil, especially near trunks and on exserted roots). Besides soil this species now is common also on fallen logs, stumps, inclined trunks (up to several meter above ground). Saraly: Common in similar habitats [05-2100]. 
D. viride (Sull. et Lesq.) Lindb. - Raifa: $\mathrm{VH}+(\# 51$, sub. D. fragilifolium); A- (present in Ariskina' herbarium sub. $D$. fragilifolium, the specimen being obviously taken from Vasil'eva collection). We found this species to be locally common in old broad-leaved stands, on old trunks of Tilia, Quercus, Acer, Ulmus, in the same areas where Neckera pennata and Anomodon longifolius are common (i.e. \#\#65, 66, 67,78, 79, 80, 81; \#\#32, 33, 37; \#\#1, 3). Saraly: One collection (\#33), on inclined trunk of Tilia in Tilia forest with Carex pilosa [05-2092].

Didymodon fallax (Hedw.) Zander - Raifa: A-. Along a road (based on calcareous gravel) across meadow, \#33 [03-28].

Drepanocladus aduncus (Hedw.) Warnst. - Raifa: K+; $\mathrm{VH}+(\# 51) ; \mathrm{A}+$ (rather common in eutrophic Carex + mossy and Carex + Sphagnum mires and in swamping forests). We collected it in old creek beds, swamps, and wet meadows. Saraly: Not rare in wet depressions and swamps in forests, and also in temporarily flooded shores of water-reservoir (in gulfs, among Typha and Phragmites), occasionally on meadows and along roads [05-2135].

D. polygamus (B.S.G.) Hedenäs - Raifa: A-. Nikolaeva \& Taktagulova (1985). We collected it on wet meadow at forest edge in \#139, and along northern shore of Dolgoe Lake, in Alnus glutinosa swamp with abundant Helodium blandowii, and also in mesotrophic mire west of Sadovyj settlement [05-2324].

Entodon schleicheri Demet. (E. cladorhhizans auct.) Raifa: VH+ (\#80, on Tilia); !A++ (\#26 - collected 15.VII.1949 and without exact place - 18.VIII.1949; reported as growing on Quercus and Pinus trunks, rare). We found it just once, on inclined Tilia in \#65, in old, rather open broad-leaved forest, sterile [03-29].

Eurhynchiastrum pulchellum (Hedw.) Ignatov et Huttunen (E. pulchellum (Hedw.) Jenn.) - Raifa: !A+ (sporadic in forests on trunks, stumps, soil). We found it also of sporadic frequency, on old trunks of broadleaved trees, and some collections from sandy-loamy soil in heaths at forest edges. Saraly: Steep banks along roads in forest on slopes; few places, but there ocurring in abundance [05-2250].

Fissidens bryoides Hedw. - Raifa: $\mathrm{K}+$; !A+ (rare on bare soil in coniferous and deciduous forests). We found this species in very few places: flood valley of Sumka Creek, on alluvium on soil and above trunks and stumps up to $50 \mathrm{~cm}$ above ground; on meadow at the shore of Raifa Lake, with c Tortula truncata. Saraly: Rare, on soil banks along the forest roads and steep slopes of ravines, once under upturned roots of fallen tree in Tilia forest, \#33 [05-2089].

F. taxifolius Hedw. - Raifa: [Krylov (1904) and Ariskina (1968) report $F$. adianthoides on soil in broadleaved forest, with Plagiomnium cuspidatum and $\mathrm{Am}$ - blystegium serpens; according to habitat this is misidentification of $F$. taxifolius]. We found it once, on steep slopes to Sumka Creek downstream from Raifa Lake, \#32 [03-30].

Fontinalis antipyretica Hedw. - Raifa: !A++ (in SerBulak Creek, rare). We failed to find this species.

Funaria hygrometrica Hedw. - Raifa: VH+ (\#11/12, 39); !A++ (common in fire-places). We saw mostly sterile plants along moist forest roads. Saraly: Sporadic on landslides to water reservoir, on relatively wet places; on concrete block at pond base. [052191].

Hamatocaulis vernicosus (Mitt.) Hedenäs - Raifa: A++ (recorded as rather frequent moss in eutrophic and mesotrophic mires, with Drepanocladus aduncus, Leptodictyum riparium, Calliergonella cuspidata; no collections are under this name, but in collection of Meesia triquetra, 26.VII.1948, is an admixture of Hamatocaulis vernicosus). We didn't find this species.

Haplocladium microphyllum (Hedw.) Broth. - Raifa: $\mathrm{VH}+(\# 81)$; not recorded by Ariskina (1968), but there is a specimen in Ariskina' herbarium ('1960'), which, seems, is a part of collection of Vasil'eva of 1929. We found this species in \#32, on old Tilia trunk as admixture to Pseudoleskella nervosa, in wet Picea +Tilia forest (where Abies is still growing now). The \#81, where this species was collected by Vasil'eva, is known as another locality of Abies, where it disappeared in recent decades (Bakin, pers. com.) [03-31].

Helodium blandowii (Web. et Mohr) Warnst. - Raifa: $\mathrm{VH}+(\# 70) ; \mathrm{A}++$ (rather rare). Locally abundant now in mires and swamps around lakes: Dolgoe, Mokhovoe, Gniloe, and west of the Sadovyj settlement [052241].

Homalia trichomanoides (Hedw.) B.S.G. - Raifa: K+; $\mathrm{VH}+(\# 37) ;$ !A+ (sporadic, on bases of Quercus and other broad-leaved trees). In old broad-leaved forests and in the valley of Sumka Creek, on trunk bases and on inclined trunks of broad-leaved trees, Populus tremula, Alnus glutinosa [03-32].

Hygroamblystegium humile (P. Beauv.) Vanderporten et al. - Raifa: A-. We found this species on wet meadow on western shore of Raifa Lake, \#29. Saraly: \#56, wet depression in Betula forest; \#10 \& 33, old wet forest roads, among grasses [05-2167; 05-2087]. Hylocomium splendens (Hedw.) B.S.G. - Raifa: VH+ (\#67); A++ (common). Dominant in coniferous forests (although somewhat less common than Pleurozium); in broad-leaved forests - mostly on rotten logs. Saraly: Sporadic in mossy pine forests [05-2015].

Hypnum cupressiforme Hedw. - Saraly: Single collection on upper surface of inclined trunk of Tilia in Tilia forest (Carex pilosa type), \#33, same place as for Dicranum viride [05-2091]. 
Leptobryum pyriforme (Hedw.) Wils. - Raifa: VH+ (\#39, with Funaria); A++ (sporadic on wet soil in forests and in swamps). We observed this species on soil banks along forest roads, in fire-prevention trenches, track pits on old roads, under upturned roots, on lake shores, in most cases in sterile condition. Saraly: Sporadic in similar habitats and in periodically flooded shores of gulfs of water-reservoir [05-2103].

Leptodictyum riparium (Hedw.) Warnst. - Raifa: $\mathrm{VH}+$ (\#38), A++ (very common in creeks and lakes, on soil, logs, stumps). Current state of this species is the same. Saraly: common on shores of water-reservoir on logs and stupms, on soil among Typha and Phragmites (the most abundant moss in this habitat), occasionally at banks of ponds, in swampy depressions, etc. [05-2143].

Leskea polycarpa Hedw. - Raifa: $\mathrm{K}+$; $\mathrm{VH}+(38)$; $\mathrm{A}+$ (rather common on deciduous trees). We observed it to be scattered along Sumka Creek and Raifa Lake, mostly on lower parts of trunks (covered by alluvium), and also near Linevo Lake, in abundance on Alnus glutinosa - on trunk bases and exserted roots, never exceeding level of snow cover. Saraly: on Salix along shore, more rarely on trunks of broad-leaved trees in more or less open forests [05-2198].

Leucodon sciuroides (Hedw.) Schwaegr. - Raifa: VH+ (\#80); !A++ (rather common on Tilia and Quercus, with Anomodon longifolius and Pseudoleskeella nervosa). We found it few times on Quercus, Acer and Tilia in broad-leaved forest in southern part of the territory ( $\# 65,66,67,80,81)$, mostly in top part of fallen trunks (two times in large quantity, both on Quercus). Saraly: Rare: several times on Tilia in \#33, and once in \#10 and \#26 [05-2342].

Meesia triquetra (Jolycl.) Aongstr. - Raifa: !A-. One collection in Ariskina herbarium, in Carex+Sphagnum bog (26.VII.1948); with Hamatocaulis vernicosus in admixture.

Mnium marginarum (With.) P. Beauv. - Saraly: Slope of ravine in \#23, in one place, but here is quite abundant [05-2251].

M. stellare Hedw. - Raifa: $\mathrm{VH}+(\# 51$, on Tilia); $\mathrm{A}++$ (on tree bases and stumps, not common). We found this species on soil on slopes of ravines, and also on bases of Tilia trunks, rather rare. Saraly: Steep soil banks in ravines and along roads on slopes; rare, but in rather large populations [05-2343].

Myrinia pulvinata (Wahlenb.) Schimp. - Raifa: ALocally common along Sumka Creek (\#19, 20, 24, $25,32,33)$, on lower parts of trunks covered by alluvium (or slightly above), on Alnus, Ulmus, Salix. Once on Betula at Raifa Lake shore [03-38].

Neckera pennata Hedw. - Raifa: $\mathrm{VH}+(\# 80)$; !A++ (on Tilia and Betula, not common). We found this species in old mixed (Tilia + Picea) and broad-leaved forests, in three separate areas of Raifa: (\#65, 66, 67, $78,79,80,81)$; (\#20, 32, 33, 37, 46); and (\#1, 3); it grows on old trees of Tilia, Ulmus, Quercus, Acer, Populus tremula. Saraly: on Tilia trunks: rare in \#25, 27, and sporadic in \#33 [05-2094].

Orthotrichum affine Schrad. ex Brid. - Raifa: A++ (sporadic on Populus tremula, with $O$. speciosum). We did not find this species.

O. gymnostomum Brid. - Raifa: A-. We found it in one place on Populus tremula in \#139 [03-40].

O. obtusifolium Brid. - Raifa: A-. On Populus tremula, Salix fragilis, more rarely on Quercus and Ulmus; not rare, although less common than $O$. speciosum and in relatively better lightened habitats. Saraly: Common of trunks of Populus tremula [05-2054].

O. speciosum Nees - Raifa: VH+ (\#81, on Quercus); !A++. Now is rather common on Populus tremula, Salix fragilis, more rarely on broad-leaved trees, and only occasionally on Betula and Alnus. Saraly: Not rare on Populus tremula and Tilia, although less common than O. obtusifolium [05-2000].

Oxyrrhynchium hians (Hedw.) Loeske (Eurhynchium hians (Hedw.) Sande Lac.) - Raifa: A++ (on soil in forest, rare). Now this species is quite common on soil in broad-leaves forests, as well as along forest roads (except dry pine forests), openings, meadows, old cuttings. Saraly: Sporadic, on soil on slopes of ravines and along more wet forest roads [05-2188].

Physcomitrella patens (Hedw.) B.S.G. - Saraly: Only in \#56, on soil around semi-permanent puddles on forest roads, in few places within about $1 \mathrm{~km}$ [052163].

Plagiomnium confertidens (Lindb. et H. Arnell) T. Kop. - Raifa: A-. We found it in swampy Alnus glutinosa forest on northern shore of Linevo Lake, \#116, with P. ellipticum [03-41]. This is the first record of this mainly East Asian species west of Ural Mountains.

P. cuspidatum (Hedw.) T. Kop. - Raifa: VH+ (\#37); !A++ (common, soil and trunk bases). Now common at trunk bases, and also on soil and rotten logs. Saraly: Common in similar habitats [05-2187].

P. drummondii (B.S.G.) T. Kop. - Raifa: $\mathrm{K}+$ (without annotations); $\mathrm{VH}+$ (\#67); !A+ (on soil in forest, (specimen: coll. Ariskina 27.VII.1948, KZN) and in forest' swamp, \#67 - the latter specimens obviously taken from Vasil'eva herbarium). Our seach of this species was unsuccessful.

P. ellipticum (Brid.) T. Kop. - Raifa: K?; VH+ (\#66, sub Mnium affine); A? It seems that Krylov and Ariskina included this species in P. affine s.l. Ariskina (1968) reported it as sporadic. Now rather common in various wet places - swamps, wet forests and meadows, slopes of ravines, creek banks, lake shores; it grows on soil, rotten logs and tree bases. Saraly: 
Sporadic in wet places on forest roads, in depressions, ravines [05-2222].

P. medium (Bruch et Schimp.) T. Kop. - Raifa: A++ (reported as sporadic, but the only her collection in KZN, 23.VII.1948, belongs to P. cuspidatum). We found it several times (\#32, 37, 46, 134N), mostly in Tilia +Picea forests, rarely in Picea+Pinus forests, on rotten logs and litter. Saraly: Rare, in ravine in \#23 and on wet road in forest, in \#25 [05-2249].

P. rostratum (Schrad.) T. Kop. - Raifa: $\mathrm{VH}+(\# 53$, ravine); $\mathrm{A}++$ (sporadic, on wet soil and exserted roots). We found it three times, at base of Tilia and on rotten $\log$, in \#32, 66 [03-42].

Plagiothecium cavifolium (Brid.) Iwats. - Raifa: $\mathrm{VH}+$ (\#53, sub P. denticulatum). A-. We found it in ravines near Dolgoe Lake and Mokhovoe Bog, and occasionally on stumps in spruce forest [05-2285].

P. curvifolium Limpr. - Raifa: A-. Sporadic on trunk bases and exserted roots (especially of Pinus, Picea, Betula), occasionally on stumps, rotten logs, etc. [0345].

P. denticulatum (Hedw.) B.S.G. - Raifa: !A+ (sporadic on exserted roots, stumps, rotten logs and on litter). Now it is a common species, occurring on rotten wood, more rarely on soil in conifer forests (including slopes, trench banks, etc.), and on tree bases. Saraly: rather rare on soil banks along roads, slopes of ravines, under upturned roots [05-2055].

$P$. denticulatum var. undulatum (P. ruthei Limpr.) Raifa: A-. Sporadic on soil and rotten wood in wet places in forest and swamp edges [03-48].

P. laetum B.S.G. - Raifa: !A- (present in Ariskina herbarium as $P$. sylvaticum). Sporadic now on rotten logs and on bases of old broad-leaved trees. Saraly: Rare on bases of Tilia and Betula, and on rotten logs [052220].

P. latebricola B. S. G. - Raifa: A-. Rare, on strongly rotten stumps in Tilia forest $(\# 65,33)$ and in Alnus glutinosa swamp (\#65) [03-54].

Platygyrium repens (Brid.) B.S.G. - Raifa: A++ (sporadic, on trunks of Quercus and Betula). Present state is similar, it occasionally occurs also on other broadleaved trees and Alnus glutinosa, and on rotten logs. Saraly: Rather rare in similar habitats, \#10, 33, 57 [05-2204].

Pleurozium schreberi (Brid.) Mitt. - Raifa: VH+ (\#40); !A++ (carpet-forming species in coniferous, especially pine forests). Now it is equally common, occurring in various forest types on soil, on fallen logs, on trunk bases, hummocks in bogs, etc. Saraly: Common in similar habitats [05-2224].

Pogonatum dentatum (Brid.) Brid. - Raifa: A-. Single collection under upturned roots of fallen tree on south shore of Dolgoe Lake (\#126) [03-57].

P. urnigerum (Hedw.) P. Beauv. - Raifa: $\mathrm{VH}+$ (along a road near Raifa monastery); !A++ (rare on ravine slopes). We found this species to be common along fire-prevention trenches and roads in forest (especially on sandy, more rarely on loamy soil), and also several times in forest under upturned roots of fallen trees [05-2326].

Pohlia andalusica (Hoehnel) Broth. - Raifa: A-. Sporadic on soil banks along roads and track pits of old roads in forest and in fire-prevention trenches; in moist to rather dry conditions [03-58].

P. annotina (Hedw.) Lindb. - Raifa: A-. Similar to previous species and sometimes mixed with it. Saraly: Sandy soil bank of road in forest, \#24 [052133].

P. cruda (Hedw.) Lindb. - Saraly: Sandy soil bank of road in forest, $\# 24$, with $P$. annotina, in one place, but in abundance [05-2150].

P. melanodon (Brid.) Shaw - Raifa: A-. Rare, on wet soil at bank of Sumka Creek and in track pits on old roads in forest, usually on loam. Saraly: in similar habitat, \#10 [05-2214].

P. nutans (Hedw.) Lindb. - Raifa: $\mathrm{K}+$; $\mathrm{VH}+(\# 26,68)$; !A+ (rather common on soil, at trunk bases, on stumps, in bogs). Current frequency and habitats are similar; not rare also along fire-prevention trenches and under upturned roots of fallen trees. Saraly: Not rare in similar habitats [05-2079].

P. wahlenbergii (Web. et Mohr) Andrews (Mniobryum wahlenbergii (Web. et Mohr) Jenn.) - Raifa: A++ (in ravine near Belobezvodnoye). We found this species common along old moist roads in forest, at lake shores, bars of Sumka and Ser-Bulak Creeks. Saraly: Old and not or little used forest roads, rare, \#10, 24 [05-2120].

Polytrichastrum formosum (Hedw.) G. L. Sm. - Raifa: $\mathrm{VH}+$ (\#67); A++ (\#26 - but probably this record belongs to $P$. pallidisetum, see below). We found this species on upturned roots of fallen tree (\#32) and along roads in Picea + Tilia forest, in \#46, 47/37 [0362].

P. longisetum (Brid.) G.L.Sm. - Raifa: $\mathrm{VH}+$ (\#36); A++ (one locality in \#68, in Carex+Sphagnum bog). We found this species sporadic under upturned roots, especially in pine-spruce(-Tilia) forests, occasionally along compartment lines. Saraly: Rather rare, under upturned roots and on hummocks in Betula swamps [05-2025].

P. pallidisetum (Funck) G.L.Sm. - Raifa: !A-. Found in Ariskina' herbarium (27.VII.1948, KZN), identified as Polytrichum attenuatum.

Polytrichum commune Hedw. - Raifa: $\mathrm{K}+$; $\mathrm{VH}+(\# 51)$; !A + (common in forests and bogs). Common in mesic to wet forests usually dominated by conifers, on openings, cuttings, mires, bogs, hummocks. Saraly: Sporadic in inter-dune hollows, occasionally along wet 
forest roads, once in relatively dry meadow [052345].

P. juniperinum Hedw. - Raifa: $\mathrm{VH}+(\# 26) ;$ ! ++ (very common). Now it is also very common on soil in forests, forest edges, along roads and trenches, occasionally on rotten logs. Saraly: Common in similar habitats, especially in dry pine forests [05-2011].

P. piliferum Hedw. - Raifa: $\mathrm{VH}+(\# 28)$; !A++ (very common, especially in dry pine forests). Now it is moderately frequent to sporadic, occurring especially on forest edges on oligotrophic meadows, in fire-prevention trenches, occasionally on rotten logs. Saraly: Sporadic, in dry pine forests with lichen in dune part of the territory [03-66].

P. strictum Brid. - Raifa: $\mathrm{VH}+(\# 70)$; $\mathrm{A}++$ (rather common in Sphagnum bogs). The same characteristic can be done now [03-69].

Pseudobryum cinclidioides (Hueb.) T.Kop. - Raifa: $\mathrm{VH}+$ (\#67); !A++ (specimen in Ariskina herbarium, labelled as collected in 1960, seems, had been taken from Vasil'eva collection). We found it few times, in Alnus glutinosa swamps and wet spruce forests, and at the edge of Mokhovoe mire [05-2253].

Pseudoleskeella nervosa (Brid.) Nyh. (Leskeella nervosa (Brid.) Loeske) - Raifa: $\mathrm{VH}+$ (\#37); A++ (common on trunks and stumps of deciduous trees). Rather common in old deciduous forests (see list of \#\#under Neckera pennata), on trunks of Tilia, Acer, Ulmus, Quercus, Salix alba, and occasionally on rotten (up to strongly) logs. Saraly: One of the most common and abundant species of tree trunks in mixed and deciduous forests [05-2006].

Ptilium crista-castrensis (Hedw.) De Not. - Raifa: VH+ (\#6, 56); !A++ (on soil and stumps, rare). Sporadic now in coniferous forests on soil and rotten logs; in the latter habitat - also in broad-leaved forests. Saraly: Rare, on rotten logs in pine forest and on swamp edge, \#61 and 62 [05-2028].

Pylaisia polyantha (Hedw.) Schimp. - Raifa: $\mathrm{K}+$; VH+ (\#81); !A+ (common on trunks, especially on Populus tremula). Very common, occurring on all deciduous trees (most abundant on aspen), sporadic on decorticated logs. Saraly: Common on aspen, somewhat more rarely on other deciduous trees [05-2021].

Rhizomnium pseudopunctatum (Bruch et Schimp.) T. Kop. - Raifa: A++ (swamp in \#67). We did not find this species.

R. punctatum (Hedw.) T. Kop. - Raifa: $\mathrm{K}+$; $\mathrm{VH}+(\# 53$, ravine); A+ (wet forests and swamps, not common). Current frequency is similar; the species occurs on soil and rotten wood in wet types of forests (including wet Tilia forests), in ravine bottoms and other wet places. Saraly: Steep slopes along old forest roads in \#23, 24 [05-2123].

Rhodobryum roseum (Hedw.) Limpr. - Raifa: $\mathrm{VH}+$ (\#49);
!A++ (rather common in coniferous and deciduous forests and swamp edges). We found this species to be sporadic on litter, mostly in forests with spruce. Saraly: One collection in $\# 59$, along a road in mesic pine forest [05-2215].

Rhytidiadelphus subpinnatus (Lindb.) T.Kop. - Raifa: $\mathrm{A}++$ (rare in conifer forests). We found it once, on broad compartment line in pine-spruce forest, \#129 [03-70].

R. triquetrus (Hedw.) Warnst. - Raifa: $\mathrm{K}+; \mathrm{VH}+(\# 48$, 67); $\mathrm{A}+$ (common in coniferous forests, forming pure carpet or growing in mixture with Pleurozium and Hylocomium). Common now too, but pure carpets are restricted mostly to forest edges. Saraly: On soil in mossy pine forest, rather rare, \#10, 61 [05-2206].

Saelania glaucescens (Hedw.) Broth. - Saraly: Soil bank of road in forest on steep slope, \#24 [05-2349].

Sanionia uncinata (Hedw.) Loeske - Raifa: $\mathrm{K}+$; $\mathrm{VH}+$ (\#67); A+ (rather common in coniferous and deciduous forests, on exserted roots, rotten logs, wet soil). The current state is the same, but requires to add also inclined trunks. Saraly: Rare, on rotten logs and steep banks along roads in forest [05-2024].

Schistostega pennata (Hedw.) Web. et Mohr - Raifa: A-. Under upturned roots of fallen trees in mixed forest with spruce, $\# 60,47$ [03-71].

Sciuro-hypnum oedipodium (Mitt.) Ignatov et Huttunen (Brachythecium curtum Lindb.) - Raifa: $\mathrm{VH}+(\# 80)$; !A++ (\#49; in swamp, rare, as Brachythecium starkei). This characteristic contradicts the current state of species that is common on soil in forests with spruce, growing also on rotten logs and stumps, tree bases in different more or less wet forests. Saraly: Sporadic on litter, rotten logs, tree bases, under upturned roots of fallen trees [05-2022].

S. reflexum (Starke) Ignatov et Huttunen (Brachythecium reflexum (Starke) B. S. G.) - Raifa: VH+ (\#80); $\mathrm{A}++$ (not common; on rotten stumps and on tree bases). Now it is quite common in broad-leaved forests on tree bases; also common on rotten logs in spruce forests. Saraly: Rather rare, on tree bases and rotten logs in old broad-leaved forests [05-2165].

S. starkei (Brid.) Ignatov et Huttunen (Brachythecium starkei (Brid.) B. S. G.) - Raifa: A: (reported by Ariskina (1968), but two specimens in her herbarium belong to $S$. oedipodium). We found it only once, on exserted roots in pine-spruce forest (\#60). Saraly: on rotten $\log (\# 61)$ and on vertical soil bank along road in forest (\#24) [05-2131].

Serpoleskea subtilis (Hedw.) Loeske (Amblystegiella subtilis (Hedw.) Loeske) - Raifa: A++ (on trunks and stumps, rather common). We recorded it locally common on Populus tremula, Quercus, Tilia, Alnus, Ulmus, usually rather high up on trunks, but sometimes at trunk bases and on stumps. Saraly: on Tilia 
and Populus tremula, at 0.1 to $1.5-2 \mathrm{~m}$ above ground, once on soil on bank of old road in forest on steep slope [05-2228].

Sphagnum angustifolium (Russ.) C. Jens. - Raifa: $\mathrm{V}+$ (mire, depressions in forest and forest bogs); $\mathrm{VH}+$ (\#70); A+. We found it in mires near the lakes Dolgoe, Mokhvoe, Gniloe and in \#65, in both wet and relatively dry parts, and in Alnus glutinosa swamps around these mires. Saraly: \#32, 41, 42, 52 - in small bogs in depressions between dunes [05-2101].

S. capillifolium Hedw. - Raifa: $\mathrm{V}+$ (bog in pine forest); VH+ (\#49); A+. On hummocks in mire near Dolgoe Lake, in wet pine forest (\#125), in boggy pine forest (\#130, 147). Saraly: \#32, 52, in wet Betula forest and in swamp dominated with Drepanocladus aduncus [05-2200].

S. centrale C. Jens. - Raifa: V+ (mire near Karasikha Lake, in boggy spruce forests and Betula + Carex swamps); $\mathrm{VH}+(\# 92) ; \mathrm{A}+($ rather common). In many eutrophic and mesotrophic mires and boggy forests. Saraly: \#32, 41, 52, in small bogs of various composition between dunes [05-2350].

S. compactum DC. - Raifa: $\mathrm{K}+$; $\mathrm{V}+$ (bog edge and along trench in pine forest); $\mathrm{VH}+(\# 40) ; \mathrm{A}+($ small bog in \#26 and in pine forest near Linevo Lake). We failed to find this species.

S. contortum Schultz - Raifa: V+ (mire near Karasikha Lake); A+. We collected this species in mesotrophic mire west of Sadovyj settlement [05-2315].

S. cuspidatum Ehrh. ex Hoffm.- Raifa: V+ (lake within a mire $) ; \mathrm{A}+($ Carex + Sphagnum mire in $\# 39$, in water). We did not find it.

S. denticulatum Brid. - Raifa: V-; !A-. One of collections of Ariskina, \#26, 18.VI.1948 KZN (sub S. subsecundum), belongs to this species.

S. fallax (Klinggr.) Klinggr. - Raifa: $\mathrm{K}+$; $\mathrm{V}+$ (forest bogs and boggy depressions, as $S$. recurvum $\mathrm{P}$. Beauv.); $\mathrm{VH}+(\# 40$, as $S$. recurvum); A+ (common in mires, boggy depressions and Ser-Bulak Creek valley). Relatively common now. Saraly: \#32, 41, 42, small bogs in depressions between dunes [05-2072].

$S$. fimbriatum Wils. - A++ (in one place, in Carex +Sphagnum bog in \#26). We collected this species in \#130, 133 (Gniloe Lake), 134N (Mokhovoe Lake), both in very wet and relatively dry parts on mires. Saraly: \#41 - Betula + Carex hummock; \#52 - small swamp with Phragmites and dominance of Drepanocladus aduncus [05-2217].

S. flexuosum Dozy et Molk. - Raifa: A++ (mire near Gniloe Lake, \#26). We found this species in Mokhovoe bog, \#134N [05-2230].

S. fuscum (Schimp.) Klinggr. - Raifa: A++ (Sphagnum bog with $S$. magellanicum). We found it on hummock in mire near Dolgoe Lake [03-72].

S. girgensohnii Russ. - Raifa: $\mathrm{K}+$; $\mathrm{V}+$ (swamps and wet swamping forests); $\mathrm{VH}+(\# 40) ; \mathrm{A}+$ (wet and swampy places in coniferous forests). We found this species to be rather common, occurring also in Betu$l a$ and Alnus forests. Saraly: swamp in Betula forest, \#32 [05-2354].

S. jensenii H. Lindb. - Raifa: A++ (Carex+Sphagnum bog; no specimens of this species were found).

S. magellanicum Brid. - Raifa: V+ (forest bogs and hummocks around tree bases); $\mathrm{VH}+(\# 49) ; \mathrm{A}+$ ( not common, in bogs). Sporadic, usually in large peatbogs or close to them. Saraly: \#32 and 52, in small bogs between dunes [05-2204].

S. majus (Russ.) C. Jens. - Raifa: V+ (Sphagnum +Carex mire); A+ (wet mires with $S$. cuspidatum, sporadic). We did not find this species.

S. obtusum Warnst. - Raifa: V+ (mire near Karasikha Lake and near Raifa monastery); $\mathrm{VH}+(\# 68)$; A+ (\#35, 68, 96). We found this species in one mire west of Sadovyj settlement [05-2322].

S. platyphyllum (Lindb. ex Braithw.) Sull. ex Warnst. Raifa: $\mathrm{V}+($ Sphagnum + Carex bogs); $\mathrm{VH}+(\# 51)$; A+ (Sphagnum +Carex bogs in \#39 and 51). Also reported by Ponomarev (1913). We failed to find this species. Saraly: \#42, edge of small bog in depression between dunes [05-2108].

S. pulchrum (Lindb. ex Braithw.) Warnst. - Raifa: A-; open parts of mires Mokhovoe (\#134N) and near Gniloe Lake (\#133) [05-2289].

S. riparium Aongstr. - Raifa: K+; V (only Krylov' record cited); $\mathrm{A}+$ (a forest swamp). We found this species a number of times in mires (in transionion to forest) and in Alnus glutinosa swamps [05-2272].

$S$. russowii Warnst. - Raifa: $\mathrm{V}+$ (edges of mires and depressions in forest); $\mathrm{VH}+(\# 49) ; \mathrm{A}+$. In small bogs in \#60, 67, 147, and around Gniloe Lake. Saraly: \#42 and 52, edges of Carex and Phragmites swamps [05-2107].

S. squarrosum Crome - Raifa: $\mathrm{K}+$; $\mathrm{V}+$ (in forest swamps and in karst depression); $\mathrm{VH}+(\# 70)$; $\mathrm{A}+$ (common in wet swamps with Betula+Alnus and Betula + Picea formations). Now common in eutrophic mires and swamps. Saraly: \#41, 52, in small bogs in depressions between dunes [05-2311].

S. subsecundum Nees-Raifa: $\mathrm{K}+; \mathrm{V}+($ Carex + Sphagnum bog with Betula); $\mathrm{VH}+(68) ; \mathrm{A}+$ (sporadic in $\mathrm{Ca}$ rex+ Sphagnum bogs, but single specimen labelled 'S. subsecumdum' from her herbarium belongs to $S$. denticulatum). We collected this species in eutrophic mires in \#31, 60, 147. Saraly: \#41, edge of Carex mire [05-2317].

S. teres (Schimp.) Aongstr. - Raifa: V+ (mire near Karasikha Lake and mire in karst depression); VH+ (70); A+ (near lakes Karasikha, Gniloe, in \#35, and along Ser-Bulak Creek). We found it in mire Mokhovoe (134N), near Gniloe Lake (\#133), and west of 
Sadovyj settlement; occurs in abundance [05-2254].

S. warnstorfii Russ. - Raifa: $\mathrm{V}+$ (swamp in Picea forest); $\mathrm{VH}+(\# 70)$; $\mathrm{A}+$. We found it in $\# 130 \mathrm{~N}$ in pinespruce forest at the edge of swamp, and also on hummocks near lakes Dolgoe and Gniloe, and in \#67 [052290].

S. wulfianum Girg. - Raifa: $\mathrm{K}+$; V+ (swamps and wet swamping forests); $\mathrm{VH}+(\# 40) ; \mathrm{A}+$ (specimens in Ariskina herbarium seems were taken from Vasil'eva collection]. We collected this species in \#60 and $130 \mathrm{~N}$, at edge of bogs [03-73].

Splachnum ampullaceum Hedw. - Raifa: A-; Mokhovoe mire $(\# 134 \mathrm{~N})$, on dung of, probably, wild boar, in few places, small sterile groups [05-2236].

Stereodon pallescens (Hedw.) Mitt. (Hypnum pallescens (Hedw.) P. Beauv.) - Raifa: $\mathrm{VH}+(\# 37,70)$; !A++ (common on trunks). Now common, usually on trunks, but also on stumps and fallen logs. Saraly: one of the most common species on trunk bases and fallen logs [05-2003].

Straminergon stramineum (Brid.) Hedenäs (Calliergon stramineum (Brid.) Kindb.) - Raifa: $\mathrm{VH}+(70)$; ! A++ (mires near Karasikha Lake and Gniloye Lake). We found it in mires near lakes Dolgoye, Gniloe, Mokhovoe, at places in abundance (\#126, 133, 134N) [052261].

Syntrichia ruralus (Hedw.) Web. et Mohr (= Tortula ruralis (Hedw.) Gaertn. et al.) - Raifa: A++ (in pine forest near Belobezvodnoe). We found it in the same place, and also along pine forest edge north of Sadovyj. Saraly: Dry pine forest with lichens not far from water-reservoir bank in \#62 and also on concrete blocks at pond bank near \#10 [05-2227].

Tetraphis pellucida Hedw. - Raifa: $\mathrm{K}+$; VH+ (\#40); $\mathrm{A}+$ (moist and shady forest, on rotten logs and stumps, sporadic). We found this species to be rather common in appropriate habitats, especially in forests with spruce, mostly on stumps, also on rotten logs and on soil under upturned roots. Saraly: Rather rare, on stumps and fallen logs in pine forests [05-2256].

Thuidium recognitum (Hedw.) Limpr. - Raifa: $\mathrm{VH}+$ (\#67); A+ (not common, at forest edges and on forest meadows). Occurs now in the same frequency and habitats. Saraly: Sporadic in same habitats [052328].

Tortula acaulon (With.) Zander (Phascum cuspidatum Hedw.) - Raifa: K+ (on loamy soil along a road).

T. truncata (Hedw.) Zander (Pottia truncata (Hedw.) Fuernr.) - Raifa: A-. On hay meadow on west shore of Raifa Lake, in few places, small populations. Saraly: In similar habitat near $\# 56$, and along forest road in \#7, 10 [03-74].

Warnstorfia fluitans (Hedw.) Loeske - Raifa: !A++ (bog edge in \#39 and along Ser-Bulak, rare. Ariskina' specimen called $W$. exannulata (\#9), also belongs to this species. We collected $W$. fluitans in mire near Dolgoe Lake, and on sandy slopes of deep karst depression in forest, occasionally in mires with hummocks [03-75].

Weissia brachycarpa (Nees ex Hornsch.) Jur. - Saraly: on sandy-loamy soil banks in lower part of landslides to water-reservoir (\#13), in shade of willows, in few places within ca. $500 \mathrm{~m}$ of the shore [05-2232].

DUBIOUS AND ERRONEOUS RECORDS

Mylia anomala (Hook.) S.Gray - A++. No specimens in Ariskina herbarium were found; so-called specimen in Vasil'eva collection belongs to Plagiochila porelloides.

Bryum funkii Schwaegr. - A++. No specimens in Ariskina herbarium were found; habitats "soil in dry pine forest" indicate misidentification of B. elegans, as $B$. funkii grows almost always on wet limestones.

Ctenidium molluscum (Hedw.) Mitt. - A++: on rotten logs. No specimens in Ariskina herbarium were found; probable misidentification of Ptilium.

Encalypta vulgaris Hedw. - Nikolaeva \& Taktagulova (1985) reported this species in the settlement Sadovyj. Very doubtful record.

Fissidens adianthoides Hedw. - $\mathrm{K}+$; $\mathrm{A}+$ : on soil in broad-leaved forest, with Plagiomnium cuspidatum and Amblystegium serpens. According to habitat it is misidentification of $F$. taxifolius.

Hygroamblystegium fluviatile (Hedw.) Loeske - A++ No specimens in Ariskina herbarium were found. One so-called specimen in Vasil'eva herbarium belongs to Drepanocladus aduncus.

H. varium (Hedw.) Mönk. (Amblystegium varium (Hedw.) Lindb.) - A++. No specimens in Ariskina herbarium were found; so-called specimen in Vasil'eva collection belongs to Sciuro-hypnum reflexum.

Schistidium apocarpum (Hedw.) B.S.G. - A++: "on sandy soil at the edge of pine forest" - very doubtful, as the habitat is impossible for this species.

Seligeria recurvata (Hedw.) B.S.G. - Nikolaeva \& Taktagulova (1985) reported this species in \#14, 20. Very doubtful record - this area has forest without any rocks.

Sphagnum palustre L. - Reported only by Ponomarev (1913). No specimens seen.

Warnstorfia exannulata (B.S.G.) Loeske (Drepanocladus exannulatus(B.S.G.) Warnst.) - A++. The only specimen in Ariskina herbarium belongs to $W$. fluitans.

Warnstorfia sarmentosa (Wahlenb.) Hedenäs (Calliergon sarmentosum (Wahlenb.) Kindb.) - A++: in boggy forest. Doubtful, as this northern species was never confirmed for Central European Russia.

\section{DISCUSSION}

We have identified three main sources of historical information on the bryophytes of Raifa.

1. Krylov's data (1880s) are very comprehen- 
sive, but they include mostly hepatics, and the published data on mosses are rather uninformative, because they include mostly common species.

2. Vasil'eva's data (1929-1931) are confined almost only to mosses with very few hepatics. Her moss collection is really complete and includes a lot of rare species.

3. Ariskina's data (herbarium of 1948 , observations in 1940-1960s) includes some obvious mistakes (mostly about rare species), but provides characteristics of abundance, which are probably relatively reliable for widespread (in that time) species.

A comparison of the above data with our collections and observations from 2003 and 2005 can be summarized as follows:

\section{EPIXYLIC BRYOPHYTES}

Ten hepatics reported by Zenkova (1951) were not found now at all. These species include Blepharostoma trichophyllum, Crossocalyx hellerianus, Leiocolea heterocolpos, Liochlaena lanceolata, Lepidozia reptans, Riccardia latifrons, R. palmata, Schistochilopsis incisa, Solenostoma sphaerocarpum, and Tritomaria exsecta. It is important to note that some of them, e. g. Lepidozia and Blepharostoma were not considered to be not rare in the latter part of the XIX century (Zenkova, 1951). Our intentional search for Lepidozia and Blepharostoma covered all the most appropriate habitats of this species, but produced no positive results.

The marked decline of epixylous hepatics is a well-documented fact in many areas, for example, Moscow Province (Ignatov \& Ignatova, 1990), Scandinavia (Sädersträm, 1988), California (Norris, 1987), etc.

\section{EPIPHYTIC BRYOPHYTES}

Most of the epiphytic species (e. g. Anomodon longifolium, Homalia trichomanoides, Pseudoleskeella nervosa) have retained their frequency. Several epiphytes were found for the first time. Among them Anomodon attenuatus (found just once) and Myrinia pulvinata (found in specific habitats in flood plain) may not be particularly noteworthy with respect to changes in the environment. However, the finding of Orthotrichum obtusifolium and O. gymnostomum is intereisting; these species usually avoid more dense forests, occurring in more or less open stands. A comparison with historical data shows that Rad- ula complanata has probably also became more frequent, and this species also grows in relatively open stands.

At the same time, Leucodon also prefers rather open stands, but its frequency has not increased, rather it has probably decreased. Similarly, Anomodon viticulosus, which has disappeared, and Entodon schleicheri, which has become exceedingly rare, are also relatively heliophylous species.

Thus, the available data does not lead to obvious interpretations of these changes or to trace any apparent tendencies in the composition of epiphytic mosses.

\section{EPIGEIC BRYOPHYTES}

We found in Raifa for the first time Blasia pusilla, Cephaloziella rubella, Isopaches bicrenatus, Lophozia excisa, Atrichum angustatum, A. tenellum, Barbula unguiculata, Bryum argenteum, B. pallens, Dicranella cerviculata, D. varia, Didymodon fallax, Pogonatum dentatum, Pohlia andalusica, P. annotina, P. melanodon, Schistostega pennata, Tortula truncata. Although it is difficult to prove that some of these species were not simply overlooked by previous authors, some of them (e. g. Blasia pusilla, Bryum argenteum, etc.) are conspicuous plants growing along road, so their appearance, or at least great expansion, seems unquestionable.

Interestingly, the available data also can be interpreted to indicate expansion of Cirriphyllum piliferum, Sciuro-hypnum oedipodium, Dicranella heteromalla, Funaria hygrometrica, Leptobryum pyriforme, Oxyrrhynchium hians, Pogonatum urnigerum, and Pohlia wahlenbergii. In the past - these species were in the past either much rarer and /or having more narrow habitat preferences. Their expansion can be linked, first of all, to the system of fire-prevention trenches that usually follow compartment lines. The constant presence of open soil allows the spread here of Leptobryum, Dicranella heteromalla, Pohlia annotina, Cephaloziella, Buxbaumia, etc. The spreading of Blasia, Pohlia melanodon, P. wahlenbergii, etc. along forest roads may be also explained by the general eutrophication of the forest, which was probably less before the XX century due to pasturing and periodical forest fires. Noteworthy too is the increase of Oxyrrhynchium hians, Sciuro-hypnum oedipodium and Cirriphyllum piliferum. Unfor- 
tunately, the lack of relevant historical documentation does not allow discussion on the impact of forest pasturing (and especially the release from pasturing) on the plant species composition.

Two other epigeic species are important to mention, although difficult to interpret, because their habitats seem still well-remained: Abietinella abietina had declined considerably in forest openings, and Plagiomnium drummondii, a rare species, was not found despite a special search. Some other species are discussed in next section.

\section{MIRE COMPLEX}

We failed to find Breidleria pratensis, Calliergon giganteum, Calliergonella cuspidata, Hamatocaulis vernicosus, Meesia triquetra, Rhizomnium pseudopunctatum, Sphagnum compactum, S. majus, S. platyphyllum. It seems that most of these species grew in a minerotrophic fen ('Karasikha') that was strongly modified by the building of settlement on its edge, which resulted in eutrophicaltion, the formation of dense Alnus glutinosa stands, and a consequent loss of fen species. However, some species, e. g., Hamatocaulis, were reported as fairly common (Ariskina, 1968). We are inclined to trust these data, despite the fact that Ariskina data are not always accurate. The parallel situation is known in Moscow Province, where Hamatocaulis vernicosus was documented as not a very rare moss in the beginning of the XX century, but Ignatov \& Ignatova (1990) found that only one population was still extanct by the 1980s over an area of about 50000 sq. $\mathrm{km}$. The drainage of wetlands and overall eutrophication were usually considered as the main reason for the decline of Hamatocaulis in the Moscow Province. These reasons, however, can be applied to Raifa only in part. Certainly, some bogs in the upper course of the Ser-Bulak were drained and the Ser-Bulak bed was at places straightened in its upper course in the mid-XX century.
On the other hand, eutrophication is an evident reason for mire change only in close proximity to the settlement of Sadovyi. In other plases it agrees with the general eutrophication of forests discussed above, but disagrees with the complete decline of Calliergonella cuspidata, which is usually becoming more abundant as a result of eutrophication (e. g. Kooijman, A. M. \& C. Bakker, 1993).

Most probably, the changes in abundance of species in this group are dependent on the general descrease of the ground water level, but this process needs more thorough studies.

\section{NON-REVEALING SPECIES}

There are some species which were more likely overlooked by previous authors or by us. We refer to group of newly discovered species, including Cephalozia lunulifolia, C. pleniceps, Cephaloziella elachista, Riccia canaliculata, Bryum moravicum, Drepanocladus polygamus, Fissidens taxifolius, Hygroamblystegium humile, Plagiomnium confertidens, Plagiothecium curvifolium, P. latebricola, Polytrichastrum formosum, Sciuro-hypnum starkei, Sphagnum pulchrum, and Splachnum ampullaceum.

Species that were not found by us include: $\mathrm{Cla}$ dopodiella fluitans*, Bryum intermedium *, B. lonchocaulon*, Fontinalis antipyretica*, Orthotrichum affine*, Polytrichum pallidisetum, Sphagnum cuspidatum, S. denticulatum, S. jensenii*, Tortula acaulon*. The asterisk indicates that there are no specimens in KZN.

\section{ACKNOWLEDGEMENTS}

We are very grateful to Oleg V. Bakin, vice-director of Volzhsko-Kamsky Reserve, for his help to this study in many ways, to all many staffs of reserve who kindly helped during field work, to curator of KZN for making to our disposal historical collections from Raifa, to V. A. Bakalin for identifiaction of species of Riccia and Mannia, and to D. Horton for correction of English of the manuscript. The work was partly supported by RFBR grant 04-04-48774 and HШ-7063.2006.4.

\section{LITERATURE CITED}

[ARISKINA, N. Р.] АРИСКИНА Н. П 1951. К флоре мхов Татарской республики. - [On moss flora of Tatarskaya Republic] Уч. зап. Казан. ун-ma [Uchen. Zapiski Kazanskogo Univ.] 111(1): 75-101.

[ARISKINA, N. Р.] АРИСКИНА Н. П. 1968. Мхи Раифского участка Волжско-Камского заповедника. -
[Bryophytes of Volzhsko-Kamskiy Reserve] Tpydbl Волжско-Камского гос. заповедника [Trudy VolzhskoKamskogo Gos. zapovednika] 1: 91-106.

[BAKIN, O. V.] БАКИН О. В. 2001. Путь к заповеднику. [Towards the reserve] В кн.: Раифа-Свияжск. Казань, Изд. Казань [In: Raifa-Sviyazhsk. Kazan, Kazan Press]: 36-45. 
[BAKIN, O. V. \& V. В. IVANOV] БАКИН О.В., В.Б ИВАНОВ 2004. Основные тенденции динамики породного состава Раифского леса. - [Main tendencies of dynamics of tree composition of Raifa forest] Проблемы использования, воспроизводства и охраны лесных ресурсов Волжско-Камского региона: Науч. чтения посвящ. 75-летию... А.И. Мурзова [Problemy ispolzovaniya, vosproizvodstva i okhrany lesnykh resursov Volzhsko-Kamskogo regiona (Nauch. chteniya posvyashchennye 75-letiyu ... A.I. Murzov)] Казань [Kazan]: 35-41.

[IVANOV, V. В.] ИВАНОВ В.Б. 1995. К вопросу об изменении породного состава хвойно-широколиственных лесов Раифы. - [On the changes in tree composition in coniferous-broad-leaved forests of Raifa] Актуальные экологические проблемы Республики Татарстан: Тез. докл. II республ. науч. конф. [Aktualnye ekologicheskie problemy Respubliki Tatarstan, (Abstr. 2d Republ. Sci. Conf.)] Казань [Kazan]: 69-70.

[IGNATOV, M. S. \& E. A. IGNATOVA] ИГНАTOB M. C., Е. А. ИГНАТОВА 1990. Contributions to the bryophyte flora of Moscow Province. - [Материальл к познанию бриофлоры Московской области] В кн: Флористические исследования в Московской области (ред. Сквориов A. K.), M., Наука [In: Skvortsov, A. K. (ed.) Floristicheskie issledovaniya v Moskovskoj oblasti]: 121-179.

KOOIJMAN, A. M. \& C. BAKKER 1993. Causes of the replacement of Scorpidium scorpioides by Calliergonella cuspidata in eutrophicated rich fens. 2. Experimental studies. - Lindbergia 18: 123-130.

[KRYLOV, Р. N.] КРЫЛОВ, П. Н. 1904. Список лиственных мхов, собранных в Казанской губернии в 1882 и 1883 г. г. С. Коржинским и П. Крыловым и определенных В. Ф.
Бротерусом. - [List of mosses, collected in Kazanskaya Province in 1882 and 1883 by S. Korzhinsky and P. Krylov and identified by V.F.Brotherus] Tруды Общ-ва Ecтествоисп.при Имп. Казанск. ун-те [Trudy Obshch. Estestvoispyt. pri Imper. Kazansk. Univ.] 39(2): 1-21.

[NIKOLAEVA, K. V. \& F. M. TAKTAGULOVA] НИКОЛАЕВА К. В., Ф. М. ТУКТАГУЛОВА 1985. К флоре мхов Раифы. - [On moss flora of Raifa] $B$ кн.: Охрана $и$ исследования заповедных экосистем Волжско-Камского края. Казань [In: Okhrana i issledovaniya zapovednykh ekosistem Volzhsko-Kamskogo kraya. Kazan]: 70.

NORRIS, D. H. 1987. Long-term results of cutting on the bryophytes of the Sequoia sempervirens forest in northern California. - Symposia Biologica Hungarica 35: 467-473.

[PONOMAREV, A. Р.] ПОНОMAPEB, А. П. 1913. К бриофлоре окрестностей г. Казани. - [On bryoflora of Kazan City surroundings] Tруды бот. сада Юрьевск. унma [Trudy Bot. Sada Yurievsk. Univ.] 14 (3): 235-237.

SÄDERSTRÄM, L. 1988. The occurrence of bryophyte and lichen species in an old natural and managed forest stands in northeastern Sweden. - Biol. Conserv. 45: 169-178.

[VASIL'EVA, L. N.] ВАСИЛЬЕВА, Л. Н. 1933. К флоре сфагновых мхов северо-запада Казанского края. - [On Sphagna of the North-West of Kazansy Region] Уч. заn. Казан. ун-та [Uchen. Zapiski Kazanskogo Univ.] 93(6, Бот. 1): 154-171.

[ZENKOVA, Е. YA. ] ЗЕНКОВА, Е.Я. 1951. Печеночные мхи из окрестностей г. Казани (по сборам проф. П. Н. Крылова). - [Hepatics from Kazan City surroundings (by collections of P.N.Krylov)] Tруды Томск ун-ma [Trudy Tomsk. Univ.] 116: 153-162. 